\title{
POSITION OF COAL IN ELECTRIC POWER GENERATION
}

$\mathrm{N}$ a modern industrial community the generation 1 of electrical power becomes one of the essential pillars of national prosperity. In Great Britain, the standards of efficiency of the generation of such power have changed markedly in the past forty years. This change amounts to an improvement in the thermal efficiency of power generation from some 18 per cent at the end of the First World War to a realizable figure of 36 per cent foreshadowed in new equipment at the present time. The coal now used for this purpose represents 84 per cent of all the fuel consumed by the Central Electricity Generating Board. In 1957 the proportion was 95 per cent. By 1965 it may fall to 80 per cent.

The why and the wherefore of these prospects were explained recently in an interesting lecture by $\mathbf{M r}$. L. Rotherham, the member for research of the Central Electricity Generating Board, on the occasion of the award to him of the British Coal Utilization Research Association's Coal Science Medal*.

Mr. Rotherham discussed the extent to which nuclear energy and oil are likely to be used within the coming decades, and the technical and economic factors affecting the situation.

In 1965-66 nuclear energy will be contributing an equivalent of 6-7 million tons of coal. This consumption of nuclear enorgy is justified not entirely on economic grounds, but in order to enable the technology of nuclear energy to be developed. By 1970-71 nuclear energy is expected to be contributing some 20 per cent of the energy output of the Board. With oil keeping its position, coal will only be used for 65 per cent of the station requirements. Nuclear energy might have come into the picture earlier; but its advancement has been affected by three principal factors, namely, a less than anticipated rise in the price of coal, improved efficiency of electricity generation and reduction in capital costs in coal-fired stations. Over the period envisaged the rate of energy consumption is anticipated to increase by some 7 per cent per annum. The position of coal varies regionally. The North-West of England is a high coal cost area. The healthy industry in Yorkshire and the Midlands can maintain a high demand for coal. Oil is competitive on the coast, where seaborne oil can compete favourably with rail-borne coal. If the energy transport problem could be overcome it would assist the use of coal from productive East Midland collieries in respect of London and the South.

Mr. Rotherham discussed the factors affecting the economics of the transport of energy. A basic factor is that three units of heat have to be transported as oil, gas or coal for one of electricity. In regard to the transmission of electricity over great distances, $400-\mathrm{kV}$. lines are preferred for reasons of amenity. A high-voltage grid is indeed a step in the direction

* British Coal Utilization Research Association Quarterly Gazette, No. 44 (1961). of advancing the economic transfer of power, and favours the greater utilization of coal. The hydraulic transport of coal is being studied, an experimental development being the delivery by such means over a distance of 2,000 yards from a colliery to a power station in Wakefield.

Important technical problems arise in the effects and disposal of the ash from the fuel, a nuisance to be paid for. It has been intensively studied, particularly in respect of overcoming the effects of the deposits on boiler surfaces, and the resultant loss of efficiency and productive plant capacity by interrupted operation. The outcome has been a marked improvement in the time in which a boiler remains on load. In this respect, substantial help in the attainment of this result has been derived from the activities of the Boiler Availability Committee, which is supported jointly by the Central Electricity Generating Board and the boiler manufacturers, the research activities being undertaken in the main by the British Coal Utilization Research Association. The limitations in the properties of materials still constitute a problem. Thus, the vulnerability of superheater metals to the corrosive effects of deposits, even if austenitic steels are used, is the main obstacle to the use of higher steam temperatures and improved efficiency in the generating plant.

The layman will be pleased to know that, although electrostatic precipitators are now used for collecting solid particles in chimney emissions to the extent of recovering 99 per cent of the emission from the boilers, the escape of the remaining 1 per cent is still regarded as unsatisfactory, and attention is being devoted to the difficult problem of its dispersion. The collected ash has useful purposes in brick-making and horticulture. When used for land reclamation the presence of toxic constituents, particularly boron and molybdenum, calls for tolerant crops in the early stages of cultivation.

Improvement in thermal efficiency is inevitably accompanied by increase of cost in the necessary complication of equipment, and new fields of electricity generation are being studied-thus fuel cells, thermionic devices and magneto-hydrodynamics.

The final picture envisaged is that coal has an assured place in the generation of electric power at the present time. The future may well depend on the outcome of research. The coal consumption required annually for electricity supply could be expected to rise above 100 million tons by 1970 . Marginal economies in utilization could have great significance. The position of coal must, nevertheless, depend largely on the price of coal. With improved methods of mining and an acceleration of research the position of coal could be maintained. Mr. Rotherham has concluded that an interesting and possibly fruitful field of development exists, given the necessary resources for the purpose. 